\title{
13. Introduction to DICKENSIAN
}

\author{
An Intertextual Universe?
}

Ian Christie

The characters in each of Charles Dickens's novels belong to that work alone. Each novel, from The Pickwick Papers to the unfinished Mystery of Edwin Drood, has its own cast and range of settings - its distinctive "world." But what if these worlds did overlap, creating a larger "Dickensian" universe in which characters might meet and jointly create new shared storylines? The result would go beyond Dickens and might be "Dickensian," but would it be Dickens? As if to test this proposition, BBC Television commissioned a unique drama series in 2015, which drew on the popular dramatic skills of one of Britain's most experienced television scriptwriters and "showrunners," to create a "Dickensian" universe across a twenty-part series.

But in what ways was this unique? From Dickens's own era, we can think immediately of Balzac's great Comédie Humaine, in which a range of characters recur in over ninety texts, some of them more than twenty times, and many others less frequently. We can also think of the great multipart or series novels of the twentieth century, which follow a small group of characters across a span of time, from Marcel Proust's À la recherche du temps perdu to Anthony Powell's A Dance to the Music of Time. Or, perhaps, the characters whose exploits are recounted in novels and stories which maintain a certain consistency of detail: in England, Sherlock Holmes and Dr. Watson, and Bertie Wooster with his servant, Jeeves, would be obvious candidates.

Early cinema would latch onto these established and widely translated favorites, and quickly translate them into screen series. Sherlock Holmes became the archetypal modern detective in a series of film adaptations from as early as 1900; while "Nick Carter" became an indefinitely extendible cypher for an American equivalent in print from 1886, and thereafter promiscuously on-screen, with no unique authorial obligations to maintain. The "franchise," referring to a named (and copyrighted) character or milieu has, of course, become a staple of modern narrative entertainment. However, the case of DiCKENSIAN (2015-2016) posed challenges over the issues of high/low culture, and the integrity of an author's work as originally conceived.

In this respect, it may be worth recalling the Wars of the Roses adaptation of Shakespeare's English history plays, first performed to wide acclaim by 
the Royal Shakespeare Company in 1963. This involved reordering four of Shakespeare's plays dealing with conflict between the Lancaster and York dynasties, and included the interpolation of new verse by the adapter, John Barton. The result, both onstage and later in television adaptation, was widely considered to have revived the reputation of some of Shakespeare's least popular plays - by reshaping them into a new dramatic form. Interfering with the central figure in English literature is clearly a different matter from adapting Dickens, long regarded as a popular rather than canonic figure. But a broader view of literary and cultural history reveals that no authors have been immune to often drastic reshaping and adaptations of their work.

Should DiCKENSIAN therefore be considered more the latest instance of this process of adapting classical authors to the formats and sensibilities of the era - like removing "brutality" from Shakespeare in the seventeenth century; or producing comic-book versions of literary classics in the twentieth century? Or did it represent a significant experiment in exploring and updating the "fictional universe" of a popular author? Or, as a product of the contemporary world of television fiction, was it closer to such series as Black Mirror (2011- ), acknowledging its debt to the earlier Sci-Fi series The Twilight Zone (1985-1989), anticipating the Sony/Amazon EleCtriC Dreams (2017- ) series, based on Philip K. Dick's stories?

Luke McKernan's essay on DicKensian, which was developed from an original blog post, explores some of these issues, while also paying tribute to a rare, and so far more unique, experiment in "popular Dickensian soapopera." Is this a path still to be followed in television fiction? 